\title{
Antibiotikapolitikk, smittevern og etikk
}

Resistensutvikling overfor antibiotika er ikke nytt, men problemet er økende. Utviklingen er blitt betegnet som en global krise og sammenliknes med trusselen fra klimaendringene. I Europa dør flere av resistente infeksjoner enn av ulykker, og vi kan i fremtiden kan stå uten effektive antibiotika mot mange infeksjoner (1-3).

Resistensutvikling har direkte sammenheng både med hvilke midler som velges og det totale forbruket. Resistensproblemene i nordiske land har vært mye mindre enn i de fleste andre land, noe som i hovedsak skyldes en mer restriktiv antibiotikabruk. Imidlertid stiger bruken også i Norden (4-6), og resistensproblemene øker både pga. større forbruk og pga. import av resistente mikrober med pasienter, turister og innvandrere (7). Hovedproblemet i Norden har vært sykehusinfeksjoner med meticillinresistente gule stafylokokker (MRSA) og i økende grad multiresistente gramnegative stavbakterier $(3,8)$. Nye MRSA-stammer har nå spredd seg i samfunnet ellers. Utenfor sykehus har penicillinresistente pneumokokker og erytromycinresistente streptokokker også vært et problem særlig i Island, Sverige og Finland. Der har en reduksjon av antibiotikaforbruket i allmennpraksis gitt redusert resistens (7).

Restriktiv bruk av antibiotika er det viktigste tiltaket for å motvirke resistensutvikling. Risikoen for uheldig resistensutvikling hos gramnegative staver har spesielt vært knyttet til bruk av fluorokinoloner og kefalosporiner $(4,9,10)$. Styring av antibiotikabruk (antibiotic stewardship) er meget viktig for forebygging av resistens og sykehusinfeksjoner $(5,6)$. Redusert bruk av fluorokinoloner og kefalosporiner har gitt færre infeksjoner både med disse mikrobene, meticillinresistente gule stafylokokker og Clostridium difficile $(9,10)$.

Det kan oppfattes som etisk problematisk ikke å gi en bredest mulig dekning med de nyeste antibiotika mot alvorlige infeksjoner, men det må være et større etisk problem å utsette de kommende generasjoner for infeksjoner vi ikke har effektive midler mot. Risikoen ved ikke å velge det bredeste alternativet er liten hvis man også tar adekvate prøver og justerer behandlingen hvis resistens påvises $(9,10)$. Valg av antibiotika ut fra fare for resistensutvikling er diskutert i flere artikler $(4-6,11)$ og gir grunnlag for eventuelt å velge det samfunnsnyttige fremfor en mulig individuell gevinst.

Smitte med resistente mikrober skjer i hovedsak ved kontakt. Håndhygiene og isolering på enerom er de viktigste mottiltakene (2). For stafylokokker og tuberkelbasiller som overlever lenge i inntørkede dråper og støv, spiller luftsmitte også en rolle selv om det for stafylokokker antas å være av mindre betydning. Både ved meticillinresistente gule stafylokokker og tuberkulose anbefales dog luftsmittetiltak og i sykehus isolering på rom med kontrollert ventilasjon. Omfattende smitteverntiltak skaper imidlertid etiske problemer med stigmatisering og reduksjon i pasientenes livskvalitet $(11,12)$. Maksimale smitteverntiltak forutsetter også samtykke fra pasienten. Eventuelle tvangstiltak vil etter smittevernloven kreve særskilt vedtak i smittevernnemnd.

For å minske ulempene for MRSA-pasienter med langtidsopphold i sykehjem har man lempet på de strenge retningslinjene ved sykehus og heller lagt vekt på de viktigste tiltakene (12). Steen og medarbeidere rapporterer i dette nummer av Tidsskriftet at det ikke har ført til økning i registrerte MRSA-tilfeller, mens det i sykehus og utenfor institusjon har vært en økning (8). Omfattende restriksjoner for pasienter med resistente mikrober har ofte ført til en ikke-akseptabel forsinkelse i utredning og behandling. Rask og god diagnostikk og sykepleie er viktig for å redusere ulempene for den enkelte pasient, og det er grunn til å understreke at smitteverntiltak ikke skal forsinke nødvendig diagnostikk og behandling (11).

Våre viktigste tiltak for å motvirke trusselen fra resistente mikrober er fornuftig antibiotikabruk i samsvar med nye nasjonale retningslinjer $(5,6)$ sammen med god hygiene og andre smitteverntiltak, men uten overdreven isolering og forsiktighet som gir reduksjon av livskvaliteten for alvorlig syke pasienter og forsinkelser i nødvendig utredning og behandling. Steen og medarbeidere har vist at modifikasjon av ellers strenge smitteverntiltak kan gjennomføres på sykehjem uten alvorlige konsekvenser $(8,12)$. En viktigere og større utfordring vil det være å fremme fornuftig antibiotikabruk globalt (2).

Johan N. Bruun

j.n.bruun@medisin.uio.no

Johan N. Bruun (f. 1936) er professor og overlege ved Universitete i Troms $\emptyset$ og Infeksjonsmedisinsk seksjon, Universitetssykehuset Nord Norge, Troms $\varnothing$, er professor emeritus og tidligere avdelingsoverlege ved Infeksjonsmedisinsk avdeling, Oslo universitetssykehus, Ullevål. Forfatter har fylt ut ICMJE-skjemaet og oppgir ingen interessekonflikter.

Litteratur

1. Tanne JH. Resistance of enterobacteria to carbapenem antibiotics is a global crisis. BMJ 2012: 344: e1646.

2. Davies SC. Annual report of the chief medical officer. Bd. 2. Infections and the rise of antimicrobial resistance. London: Department of Health, 2011.

3. Dahle UR, Wester AL, Samuelsen $\emptyset$ et al. Siste skanse for effektive antibiotika? Tidsskr Nor Legeforen 2012; 132: 1725-6.

4. Lindemann PC. Haldorsen BC, Smith I et al. Aminoglykosider bør fortsatt brukes i empirisk sepsisbehandling. Tidsskr Nor Legeforen 2013; 133: 1054-5.

5. Helsedirektoratet. Nasjonal faglig retningslinje for bruk av antibiotika i sykehus. www.helsedirektoratet.no/sites/antibiotikabruk-i-sykehus (29.8.2013).

6. Helsedirektoratet. Nasjonale faglige retningslinjer for antibiotikabruk i primærhelsetjenesten. www.helsedirektoratet.no/publikasjoner/nasjonale-fagligeretningslinjer-for-antibiotikabruk-i-primærhelsetjenesten (29.8.2013).

7. Bruun JN. Import av resistente bakterier. Tidsskr Nor Lægeforen 2001; 121 156.

8. Steen TW, Jørgensen SB, Garder KM et al. MRSA-funn i sykehjem i Oslo 2005-11. Tidsskr Nor Legeforen 2013; 133: 1819-23.

9. Dancer SJ, Kirkpatrick P. Corcoran DS et al. Approaching zero: temporal effects of a restrictive antibiotic policy on hospital-acquired Clostridium difficile, extended-spectrum $\beta$-lactamase-producing coliforms and meticillin-resistant Staphylococcus aureus. Int J Antimicrob Agents 2013; 41: 137-42.

10. Schön T, Sandelin LL, Bonnedahl J et al. A comparative study of three methods to evaluate an intervention to improve empirical antibiotic therapy for acute bacterial infections in hospitalized patients. Scand J Infect Dis 2011; 43: 251-7.

11. Braut GS, Holt J. Meticillin-resistant Staphylococcus aureus infection-the infectious stigma of our time? J Hosp Infect 2011; 77: 148-52.

12. Steen TW, Garder KM, Kadiric S et al. MRSA-avdelinger i sykehjem i Oslo. Tidsskr Nor Legeforen 2013; 133: 1800-1. 